\title{
Shariah Audit Certification Contents: Views of Regulators, Shariah Committee, Shariah Reviewers and Undergraduate Students
}

\author{
Zurina Shafii ${ }^{1}$, Supiah Salleh ${ }^{1}$, Nurazalia Zakaria ${ }^{1}$, Mustafa Mohd Hanefah ${ }^{1}$, Nor Aishah Mohd $\mathrm{Ali}^{2}$, \& Rochania \\ Ayu Yunanda ${ }^{3}$ \\ ${ }^{1}$ Faculty of Economics and Muamalah, Islamic Science University of Malaysia, Malaysia \\ ${ }^{2}$ Faculty of Accounting, Universiti Teknologi MARA Melaka, Malaysia \\ ${ }^{3}$ Islamic Accounting Department, Tazkia University College of Islamic Economics, Bogor, Indonesia \\ Correspondence: Zurina Shafii, Faculty of Economics and Muamalah, Islamic Science University of Malaysia, \\ Malaysia. E-mail: zurina.shafii@usim.edu.my
}

Received: January 30, 2014

Accepted: February 21, 2014

Online Published: April 25, 2014

doi:10.5539/ijef.v6n5p210

URL: http://dx.doi.org/10.5539/ijef.v6n5p210

\begin{abstract}
Shariah Audit certification will show the stakeholders that Shariah auditors are skillful and competent in their field. Shariah audit practices should be identified at the professional and certified level. There should be a 'Certified Shariah Auditor' to ensure that the Shariah auditor is proficient to perform the task. This issue can be resolved through the certification program. Shariah audit is considered a new area in Islamic finance. It assures that institutions embracing Islamic finance are true to the Shariah principles by them having to undergo periodical audit on Shariah matters. There is a gap in the industry to the certification of Shariah audit as currently no certification is required for Shariah auditors, and there is no professional body offering Shariah audit certification. This research aims to identify the content/scope/ of Shariah audit certification. Data were collected through questionnaire survey method. The subjects for questionnaire distribution are the regulators, Shariah Committee members, Shariah Reviewers in the Islamic banks and undergraduate students. This study contributes on the contents for Shariah audit certification program. The results reveal that Shariah audit certification should at least cover the scope of Shariah audit outlined by Bank Negara Malaysia (BNM), financial statements and internal control systems of an Islamic bank. The contents of certification may also include the area of business policies, process and procedures, zakat calculation and payment, contracts and agreements, and assessment of financial resources. This study implicates that certification in this area will promote professionalism and improve the conduct of Shariah audit in the industry.
\end{abstract}

Keywords: shariah audit scopes, shariah professional body, shariah audit certification

\section{Introduction}

The total assets of Islamic financial industry have been growing fast for the past decades. The assets reached USD 1.6 trillion at the end of 2012 which increased to $20.4 \%$ as compared to the previous year (IFSB, 2013), and it is expected to reach USD 1.9 trillion (KFH, 2013). Considering the rapid growth, it is crucial that the Islamic financial industry should have a proper 'check and balance' mechanism in the form of auditing which suits the objectives and missions of its formation, the 'maqasid al-shari'ah'(Yaacob \& Donglah, 2012). Shariah audit is deemed important to fulfil the mechanism. According to Shariah Governance Framework of BNM, the Shariah audit function refers to regular assessment on Shariah compliance in the activities and operations of the IFI by qualified Shariah officer(s), with the objective of ensuring that the activities and operations carried out by the IFI do not contravene with the Shariah. It is argued that Shariah audit must be done by qualified and competent officers.

Certification can be a means to demonstrate the ability and qualifications. The primary aim of a certification audit is to examine whether existing quality, processes and activities comply with the standard requirements (Poksinska et al., 2006). Therefore, Shariah audit certification should be implemented in the Islamic financial industry since it enhances the auditors to demonstrate their competency and proficiency in the Shariah auditing field. Shariah audit certification is more than just proof of their knowledge and achievements. It is also an assurance to the stakeholders that the Shariah auditors are professionals and prepared to meet today's challenges. 
Shariah audit certification will enrich the candidates with educational experience, Shariah and auditing skills, information, and business tools that can be applied immediately in any organization or business environment.

The current practice shows that each IFI conducts its own Shariah audit trainings (Shafii et al., 2013). However, there is an issue that highlights on the eligibility of the knowldege and skills of the trainers that conduct trainings in Shariah audit. Shariah auditors can ensure compliance with Shariah if they are aware of Shariah issues and Shariah rulings. Kasim (2012) states that in modern business environment, the challenge for Islamic scholars is to interpret Islamic principles in a manner that meets the modern day requirements but at the same time does not jeopardise the protection and promotion of the Islamic identity. Therefore, Shariah auditors' performance would be questionable if they do not understand the essence of fatwa and Shariah rulings. For certain professions, certification is required to ensure the competence and expertise in particular fields. For instance, accountants and auditors are required by law to be certified as 'Certified Public Accountant' or 'Certified Internal Auditor'. Since Shariah audit demands specific skills and proficiency, it should also aim to be recognized at the professional level. There should be a 'Certified Shariah Auditor' to ensure that the Shariah auditor is capable of performing audit as well as ensuring Shariah compliance. The issue can be resolved through the certification program in Shariah audit.

Another problem Shariah audit is considered new in auditing practices. Audit scope is to give an assurance that the practices are in line with certain standards. The current standards which are based on conventional framework seem insufficient to guide the Islamic Financial Institutions (IFIs) (Sarea \& Hanefah, 2013). Shariah should depicts the Islamic judgments and rulings. Hence, Shariah audit must be performed by a qualified auditor who should be knowledgeable in Syariah (Kasim, 2009). Shariah audit certification should accommodate audit competence and Shariah understandings. Accordingly, the objective of this research is to identify the content/scope/area of Shariah audit certification.

\section{Literature Review}

\subsection{Regulatory Requirement for Shariah Audit}

Islamic financial institutions in Malaysia are governed by the Islamic Banking Act, Bank Negara Malaysia's Shariah Advisory Council and IFSB standards. Every IFI has its own Shariah audit framework. Shariah audit is currently been performed by the IFIs in Malaysia in order to ensure that the activities and operations of an IFI are adherence to Shariah. This is in line with the Shariah Governance Framework (BNM, 2010) requirements on the implementation of Shariah audit in the IFIs. According to Shariah Governance Framework issued by Bank Negara Malaysia (2010) paragraph 7.7, "Shariah Audit refers to the periodical assessment conducted from time to time, to provide an independent assessment and objective assurance designed to add value and improve the degree of compliance in relation to the IFI's business operations, with the main objective of ensuring a sound and effective internal control system for Shariah compliance."

The Shariah Governance Framework (Bank Negara Malaysia (BNM), 2010) defines the responsibility of conducting Shariah audit lies in the hands of the internal audit unit. This signals that the responsibility of internal auditor has been expanded. The internal auditor not only act as the key of corporate governance as well as internal consultancy (Stewart \& Subramaniam, 2009), but the role has been expanded to perform Shariah audit in ensuring that the operations of the IFI are Shariah compliant. This leads to the issue of competency of the auditor and auditor's performance in performing new task which has been outlined in the Shariah Governance Framework (Bank Negara Malaysia (BNM), 2010).

Islamic Financial Services Board (IFSB) through its Shariah Governance Standard (2009) strongly recommends Islamic financial industry to develop an internal Shariah audit by having Shariah officers with appropriate qualifications and experience. Specific criteria of Shariah audit officers are mentioned in the Standard. They must be competent and have good character comprising honesty, integrity, fairness and reputation. The IFIs should ensure that they should at least possess the appropriate knowledge and skills in order for them to adequately execute their duties and responsibilities. It is also emphasized in Accounting and Auditing Organization for Islamic Financial Institutions (AAOIFI) that the Shariah auditor shall be knowledgeable about Shariah rules and principles, but would not possess the same level of knowledge as that of SSB members, and thus the auditor shall not be expected to provide interpretation of these rules and principles. The fatwas, rulings and guidance issued by the Shariah Supervisory Board (SSB) form the basis on which the auditor considers whether the IFI has complied with Shariah rules and principles.

\subsection{Competency of Shariah Auditor}

Flint (1988) stated that audit competence requires both knowledge and skill, which is the product of education, 
training and experiences. In a standard issued by International Federation of Accountants (IFAC) on International Education Standard (IES) 8 Competence Requirements for Audit Professional, outlines that auditors must have the formal education (knowledge) relevant to audit (IES 2), professional skills (IES 3) and be able to apply the professional values, ethics and attitudes (IES 4) to different contexts and organizations. Based on these definitions, it is clear that auditors' competence is determined by considering a set of relevant attributes such as knowledge, skill and attitudes. Thus, the internal auditors who are attached to the IFI must not only have the auditing skills but also need to have an additional qualification which is Shariah knowledge specifically in Fiqh Muamalat. This is to ensure proper Shariah audit has been conducted and that the overall operations of IFIs are Shariah compliant.

According to Institute of Internal Auditors Malaysia (IIAM) 2010, the internal audit unit should be appropriately staffed in terms of numbers, grades, qualifications and experience, having regard to its responsibilities and objectives. The internal auditor should be properly trained to fulfil all his responsibilities (paragraphs 15 to 26). The effectiveness of internal audit depends substantially on the quality, training and experience of its staff. The aim should be to appoint staff with the appropriate accounting and Shariah background, personal qualities and potential. Thereafter, steps should be taken to provide the necessary experience, training and continuing professional education. It is argued that accountants and auditors lack qualifications, knowledge and experience on Shariah especially among Shariah personnel, and lack of accountability of Shariah auditors (Karim, 1990; Yaacob, 2012; Yahya \& Mahzan, 2012). Abdul Rahman (2008) argues that one of the challenges in implementing Shariah audit would be to produce competent and independent Shariah auditors. He also suggested that the education and training program on Shariah audit should equip the Shariah auditor with two basic knowledge i.e. specialised Shariah knowledge as applied in Islamic banking and finance, and accounting and auditing knowledge and skills. In order to fulfil the current needs on the competency and qualification level of a Shariah auditor, there is a need for a certification program on Shariah audit. Certification program on Shariah audit will satisfy the industry demand on Shariah and finance knowledge, competency and qualification level as a Shariah auditor. For Shariah audit to be implemented correctly there is a need for certification.

In the most recent study, Shafii et al. (2013) found that competency of Shariah auditor shall be determined by each of the Islamic Banks, well equipped with both accounting and Shariah knowledge. From the focused group interview, the study found that the internal auditors may invite the Shariah team to be involved in performing Shariah audit and if the bank has an experienced staff without qualification in accounting and Shariah, it should send the staff for Shariah trainings.

\subsection{Shariah Audit Certification}

Auditing and certification practices play a key role in most accountability processes which permeate modern society, being viewed by many as an obligatory point of passage in producing legitimacy in the eyes of a large array of stakeholders (Boiral \& Gendron, 2011). Currently, there is no professional body or institution that offers Shariah audit certification. However, there are few institutions that provide trainings in Shariah audit such as CERT, Redmoney and AsiaBIS. These trainings are conducted based on the demand that the Shariah auditor must be well equipped with necessary skills and knowledge to conduct Shariah audit. The Shariah auditor in the IFIs should continuously upgrade their technical knowledge with the current issues in Shariah audit. Due to that, with the current practice that was already in place, the industry should move into the next stage which is to propose a Shariah audit certification on Shariah auditor. This is to complement the existing practise held in the industry on Shariah audit to a wider dimension.

In the Middle East, Accounting, Auditing of Islamic Financial Institutions (AAOIFI) has initiated a certification on Shariah advisor and auditor. The certification issued by AAOIFI is also known as 'Certified Shari'a Adviser and Auditor' (CSAA). CSAA program is designed to equip candidates with the requisite technical understanding and professional skills on Shariah compliance and review processes for the international Islamic banking and finance industry. CSAA program covers technical subjects that are essential to Shariah compliance and review processes and procedures such as AAOIFI's Shariah standards on Islamic finance products and practices, AAOIFI's governance standards on Shari'a compliance and review processes, Islamic banking and finance supervision, and also the application of Shariah and Fiqh (Islamic jurisprudence) to Islamic banking and finance practices.

Through the CSAA program, the respected candidates will gain advanced knowledge on the roles and functions of various Shariah compliance and review processes in financial institutions. They will able to correlate between a financial institution's Shariah Supervisory Board (SSB) and its internal Shariah compliance and technical review of banking and financial operations processes. The program also provides the candidates with mechanism 
to ensure Shariah compliance is in accordance to resolutions and fatwas (Scholars' rulings) issued by SSB.

In addition to that, in practicing Shariah audit in the IFIs, there are still lacking in terms of satisfying the general public and the clients of the IFI (Mufti Aziz Ur Rehman, 2012). He added that it is insufficient to say 'our Shariah Board approved' but it is the responsibility of the Shariah auditor to convince the client and prove the superiority of Islamic financial products in contrast to the conventional. This is because the level of public awareness on the Islamic financial products is poor. Thus, due to that, he recommended that the practice of Shariah audit shall be improved and strengthened in terms of formal official Shariah audit training and the establishment of some prequalification to be accepted on an AAOIFI CSAA study course to enhance the value and standing of the certificate. Standardization of Shariah audit procedures and more detailed standards for Shariah audit and governance are needed. Other than that, he strongly point out the needs to have a proper formal official Shariah trainnings or Shariah audit certification.

\section{Research Methodology}

This research collects data through questionnaire survey method. The instruments used in this research are a mail survey questionnaire and a direct questionnaire. The target respondents read the questions themselves and mark answers on a questionnaire. The subjects for questionnaire distribution are the regulators, the Shariah Committee, the Shariah Reviewer in the Islamic banks and the undergraduate students.

The questionnaires are divided into two types; those distributed to Shariah Committee, Shariah reviewers, regulators and those distributed to students. The questionnaires were distributed to undergraduate students to gain the general opinion on Shariah audit certification. The questionnaire is designed to obtain the information on the undergraduate final year students' perspective, awareness and understanding on the term and concept of Shariah audit in Malaysia. The respondents are students of the two selected Malaysian public universities. First group consists of final year students who have been taught Shariah auditing as part of their course syllabus. These students are selected because they have to learn Al-Tadqiq Al-Shari'e course (Arabic word for Shariah audit) as part of their course syllabus requirement. In the previous semester, they were also taught Fiqh Muamalat as part of their course requirement. The second group is final year students who learnt only conventional auditing course offered by a local university specifically Bachelor of Accountancy. A number of questionnaires were distributed to 380 students consisting of 200 students of the first group and 180 students of the second group.

The first section of the questionnaire purported to obtain the demographic information of the respondents. The next sections consists of questions posed on the level of awareness and knowledge of Shariah audit of the respondents and also questions on perception regarding Shariah audit practice in Malaysia in the form of Likert scales of five; ranging from (1) strongly disagree and (5) strongly agree. However, ranging from (1) to (5) with indication of strongly disagree and strongly agree. A total of 180 and 200 questionnaires were hand administered to the respondents but only 351 are considered valid.

The other set of questionnaires were distributed to the individuals that directly related to the operations and Shariah compliance in 22 IFIs having their operations in Malaysia. The lists of IFIs were gathered through the BNM website. The target population in this study is defined as all individuals in Islamic banks who are aware of Shariah audit practices. They consist of Shariah Committee; Shariah reviewers and regulators. The regulators are representatives from Jabatan Perbankan, Insurans dan Takaful (JPIT) department and other related departments of BNM are included in the population due to their responsibilities to oversee the overall operations of Islamic banks. Descriptive statistics was used to analyze the questionnaires.

Table 1. Distribution of the survey questionnaires

\begin{tabular}{lcccc}
\hline \multicolumn{1}{c}{ Subjects } & Population & Sample distribution & Sample representative & Received \\
\hline Shariah Committee & 113 & 65 & $39 \%$ & 12 \\
Shariah Reviewer & 110 & 64 & $39 \%$ & 13 \\
Regulators (BNM) & 60 & 36 & $22 \%$ & 28 \\
TOTAL & 283 & 165 & $100 \%$ & 53 \\
\hline
\end{tabular}

From the above table, the respond rate of the study is $32 \%$, which is considered adequate. Previous study conducted by Kasim (2009) on Shariah audit, the sample used for the study is approximately 155 respondents using similar target group. The study managed to receive 53 responses from the total sample. Shariah committee members, Shariah reviewer and regulators (BMN) were identified as primary parties involved in Shariah audit 
practices.

\section{Analysis and Discussion}

All data are based on a 5 point-Likert-based scale, which is considered as ordinal data. The scale ranges from (1) strongly disagree to (5) strongly agree. The study utilized a non-parametric test in all the analyses performed. The reliability analysis was performed to test the reliability coefficient of the data using the Cronbach alpha. The Cronbach alpha coefficient for the first set of questionnaire (undergraduate students) is 0.71 , which is slightly lower than the pilot study score but is acceptable for the further analysis. Nunally as cited in (Pallant, 2011) recommended a minimum of 0.7 Cronbach alpha value to be fulfilled before the data can be used for further analysis. For the second set of questionnaire (Shariah Committee, Shariah reviewers and regulators) the alpha value is at 0.72 which is considered to have internal consistency and hence reliable.

\subsection{Undergraduate Students}

Table 2. Distribution of respondents by gender $(n=351)$

\begin{tabular}{ccc}
\hline Gender & Frequency & Percentage \\
\hline Male & 86 & 24.5 \\
Female & 265 & 75.5 \\
\hline
\end{tabular}

The questionnaires were distributed to 380 undergraduate students and 351 questionnaires were considered valid. Table 2 indicates that out of 351 respondents, 265 are females representing a $75.5 \%$ of the samples and 86 males representing $24.5 \%$.

Table 3. Awareness of Shariah audit $(n=351)$

\begin{tabular}{ccc}
\hline Answer & Frequency & Percentage \\
\hline Aware & 271 & 77.2 \\
Not aware & 80 & 22.8 \\
\hline
\end{tabular}

The Table 3 above shows that majority of the respondents, 77.2\% are aware of the term Shariah audit. This indicates that Shariah audit is familiar to undergraduate students.

Table 4. Perception on general Shariah audit (mean score)

\begin{tabular}{clc}
\hline No & \multicolumn{1}{c}{ Statements } & Mean \\
\hline 1 & It is important to develop Shariah framework & 4.62 \\
2 & Shariah audit framework is similar to conventional audit & 2.09 \\
3 & Shariah audit framework should differ from conventional audit & 4.30 \\
4 & Broader scope of Shariah auditing & 3.53 \\
5 & Shariah auditing should confine to financial statements audit only & 2.22 \\
\hline
\end{tabular}

Table 5. It is important to develop the Shariah audit framework $(n=351)$

\begin{tabular}{cccc}
\hline Strongly Disagree (1) to Strongly Agree (5) & Frequency & Percentage \\
\hline 1 & 3 & 0.9 \\
2 & 1 & 0.3 \\
3 & 17 & 4.8 \\
4 & 84 & 23.9 \\
5 & 246 & 70.1 \\
\hline
\end{tabular}

On the development of Shariah audit framework, $70.1 \%$ strongly agree that it is important to develop the Shariah audit framework. Other than that, $23.9 \%$ agree. The mean score 4.62 shows that the respondents' opinions tend to strongly agree. 
Table 6. Shariah audit framework is similar to conventional audit $(\mathrm{n}=351)$

\begin{tabular}{cccc}
\hline Strongly Disagree (1) to Strongly Agree (5) & Frequency & Percentage \\
\hline 1 & 134 & 38.2 \\
2 & 103 & 29.3 \\
3 & 74 & 21.1 \\
4 & 27 & 7.7 \\
5 & 13 & 3.7 \\
\hline
\end{tabular}

The table shows that $38.2 \%$ respondents strongly disagree that Shariah audit is similar with conventional framework, and $29.3 \%$ of the respondents disagree with the similarity. It indicates that more than a half of the respondents (67.5\%) disagree that Shariah audit framework is alike conventional audit. Only $3.7 \%$ strongly agree that the framework is the same. The mean score is 2.09 which can be concluded that the respondents disagree that Shariah audit and conventional audit are similar.

Table 7. Shariah audit framework should differ from conventional audit $(\mathrm{n}=351)$

\begin{tabular}{cccc}
\hline Strongly Disagree (1) to Strongly Agree (5) & Frequency & Percentage \\
\hline 1 & 12 & 3.4 \\
2 & 7 & 2.0 \\
3 & 36 & 10.3 \\
4 & 103 & 29.3 \\
5 & 193 & 55 \\
\hline
\end{tabular}

From Table 4, the mean score (3.53) indicates that the responses are more toward agree that Shariah audit framework should distinct from conventional audit. Total of $79.3 \%$ of the respondents strongly agree and just agree that the theoretical framework should differ and only 3.4\% disagree that the theoretical framework should differ. The result is consistent with the previous question asking the similarity of Shariah audit framework with the conventional framework.

Table 8. Broader scope of Shariah auditing $(\mathrm{n}=351)$

\begin{tabular}{cccc}
\hline Strongly Disagree (1) to Strongly Agree (5) & Frequency & Percentage \\
\hline 1 & 46 & 13.1 \\
2 & 42 & 12 \\
3 & 52 & 14.8 \\
4 & 101 & 28.8 \\
5 & 110 & 31.3 \\
\hline
\end{tabular}

The mean score of broader scope of Shariah auditing is 3.53 . Table 8 shows that $31.3 \%$ and $28.8 \%$ strongly agreed and agreed respectively that it should be broader than conventional auditing. $14.8 \%$ of the respondents were neutral with $12 \%$ disagreeing and $13.1 \%$ strongly disagreeing.

Table 9. Shariah auditing should confine to financial statements audit only ( $\mathrm{n}=351)$

\begin{tabular}{ccc}
\hline Strongly Disagree (1) to Strongly Agree (5) & Frequency & Percentage \\
\hline 1 & 109 & 31.1 \\
2 & 119 & 33.9 \\
3 & 74 & 21.1 \\
4 & 35 & 10 \\
5 & 14 & 4 \\
\hline
\end{tabular}

Only $14 \%$ of the respondents agree and strongly agree that Shariah audit should be limited to financial statement audit while $65 \%$ disagree. It means that Shariah Audit is expected to have broader scope of audit. The mean (2.22) also shows that the response rate is more towards neutral. 
The results indicate that majority of the undergraduate students are aware of the term Shariah audit even though they have not been taught that subject. The respondents feel that it is important to develop Shariah audit framework because it is not similar with conventional framework. Therefore, the scope of Shariah audit should be broader than conventional audit. These results provide primary indication that can help the discussion on the contents of Shariah audit certification that it should be more than just financial statement audit.

\subsection{Regulators and Shariah Committee}

The survey instrument comprised a set of questions designed to elicit opinions on the framework, scope, competency, role and nature of Shariah auditing, regulations, reporting and also a set of questions to identify the elements associated with the Shariah auditors' performance. From the questions, the study can highlight the contents that should be included in Shariah audit certification. Therefore, the findings will only highlight the scope of Shariah audit for the purpose of certification content in order to meet the objective of the paper.

Table 10. Perception on general content of Shariah audit certification (mean score)

\begin{tabular}{lcccc}
\hline & $\begin{array}{c}\text { Shariah } \\
\text { Committee } \\
(\mathbf{n = 1 2})\end{array}$ & $\begin{array}{c}\text { Shariah } \\
\text { Reviewer } \\
(\mathbf{n = 1 3})\end{array}$ & $\begin{array}{c}\text { Regulators } \\
\text { (BNM) } \\
(\mathbf{n = 2 8})\end{array}$ & Mean value \\
\hline $\begin{array}{l}\text { The current scope of Shariah audit outlined by BNM } \\
\text { in SGF are not sufficient }\end{array}$ & 3.000 & 3.33 & 2.53 & 2.83 \\
$\begin{array}{l}\text { The internal auditors should attest the financial } \\
\text { statements of the Islamic banks for Shariah } \\
\text { compliance }\end{array}$ & 4.25 & 4.11 & 3.35 & 3.67 \\
$\begin{array}{l}\text { Shariah audit should cover the Internal control } \\
\text { system of an Islamic bank. }\end{array}$ & 4.50 & 4.33 & 4.21 & 4.32 \\
$\begin{array}{l}\text { The scope on compliance covers organizational, } \\
\text { structure, people, and process and information } \\
\text { technology only. }\end{array}$ & 3.83 & 3.22 & 3.21 & 3.43 \\
\hline
\end{tabular}

Table 11. The current scope of Shariah audit outlined by BNM in SGF is not sufficient $(n=53)$

\begin{tabular}{lcc}
\hline \multicolumn{1}{c}{ Responses } & Frequency & Percent \\
\hline Strongly Disagree & 2 & 3.8 \\
Disagree & 19 & 35.8 \\
Somewhat agree & 20 & 37.7 \\
Strongly agree & 2 & 3.8 \\
\hline
\end{tabular}

In general, the current scope of Shariah audit outlined by BNM in SGF is sufficient. This is supported by the mean value of respondents: 2.83 . It reflects that most of the respondents disagree with the statement that the current scope of Shariah audit is not sufficient. Based on Table 10 above 35.8\% and 37.7\% 'disagree' and 'somewhat agree' with the scope of Shariah audit as per BNM's SGF. This study also investigated the perception of respondents on the general scope of Shariah audit. The table shows that it is slightly different between those who agree and disagree.

Table 12. The internal auditors should attest the financial statements of the Islamic banks for Shariah compliance $(\mathrm{n}=53)$

\begin{tabular}{lcc}
\hline \multicolumn{1}{c}{ Responses } & Frequency & Percent \\
\hline Strongly Disagree & 4 & 7.5 \\
Disagree & 4 & 7.5 \\
Somewhat agree & 7 & 13.2 \\
Strongly agree & 28 & 52.8 \\
\hline
\end{tabular}

Table 11 clearly shows that $52.8 \%$ of the respondents 'strongly agree' that the internal auditors who act as the Shariah auditors should attest the financial statements of the Islamic banks for Shariah compliance. Respondents from Shariah committee and Shariah Reviewer agree on the statement since the mean score for each group is 
4.25 and 4.11 respectively. However, the regulators view differently as the mean score is only 3.35 . The current auditing practice in the Islamic banks is done by the external auditors during the statutory audit. Thus, the internal auditors of the Islamic banks that perform Shariah audit will not repeat the job done by the external auditors. However, based on the survey, it is necessary for the internal auditors to attest the financial statement of the Islamic banks especially on the Shariah issues in the financial statements.

Table 13. Shariah audit should cover the internal control system of an Islamic bank ( $\mathrm{n}=53)$

\begin{tabular}{lcc}
\hline \multicolumn{1}{c}{ Responses } & Frequency & Percent \\
\hline Strongly Disagree & 1 & 1.9 \\
Disagree & 1 & 1.9 \\
Somewhat agree & 31 & 58.5 \\
Strongly agree & 20 & 37.7 \\
\hline
\end{tabular}

Table 12 shows that $96.2 \%$ agree that Shariah audit should cover the internal control system of an Islamic bank. The mean value shows an average of 4.32 responses. According to an Internal Control for Shariah compliance should be designed and operated to provide reasonable assurance that an IFI's objectives are achieved in the following categories: effectiveness and efficiency of operations, reliability of financial reporting, and compliance with applicable laws, regulations, accounting and auditing standards. It can be emphasized that the certification should also include the skill and knowledge on internal control system.

Table 14. The scope on compliance covers organization, structure, people, process and information technology only $(\mathrm{n}=53)$

\begin{tabular}{lcc}
\hline \multicolumn{1}{c}{ Responses } & Frequency & Percent \\
\hline Disagree & 14 & 26.4 \\
Somewhat Disagree & 13 & 24.5 \\
Agree & 15 & 28.3 \\
Strongly agree & 11 & 20.8 \\
TOTAL & 53 & 100 \\
\hline
\end{tabular}

Based on SGF (BNM, 2010) the scope on compliance covers organizational structure, people, and process and information technology. About $26.4 \%$ disagree on it. $28.3 \%$ agree that Shariah compliance should cover the areas in SGF (BNM, 2010) only. However, based on Table 9, the mean value for this statement is 3.43 which shows that the respondents are 'somewhat agree' with the statement. Thus, it can be concluded that, additional respondents are needed to gather more evidence on the extended scope of Shariah compliance since most of the respondents are neutral with the statement.

\subsection{Contents of Shariah Audit Certification}

Table 15. Perception on extended contents in Shariah audit certifications (mean score)

\begin{tabular}{lllllll}
\hline Content & $\begin{array}{l}\text { Shariah } \\
\text { Committee }\end{array}$ & $\begin{array}{l}\text { Shariah } \\
\text { Reviewer }\end{array}$ & $\begin{array}{l}\text { Regulators } \\
\text { (BNM) }\end{array}$ & Mean Value & Frequency & \% \\
\hline Business policies & 4.41 & 4.51 & 4.28 & 4.24 & 31 & 58.5 \\
Process and procedures & 4.50 & 4.33 & 4.53 & 4.47 & 26 & 49.1 \\
Zakat calculation and payment & 4.50 & 4.33 & 4.46 & 4.43 & 26 & 49.1 \\
Contracts and agreements & 4.58 & 4.33 & 4.57 & 4.52 & 28 & 52.8 \\
$\begin{array}{l}\text { Assessment of financial } \\
\text { resource management }\end{array}$ & 4.41 & 3.55 & 4.28 & 4.20 & 26 & 49.1 \\
\hline
\end{tabular}

The results of this study indicate that majority of the undergraduate students think that the scope of Shariah audit should be broader than conventional audit. Therefore, Shariah audit certification should at least cover the scope of Shariah audit outlined by BNM. The undergraduate students' opinion is in line with the responses of Shariah Committee, Shariah Reviewer and regulators. From their responses, it can be concluded that Shariah auditors 
must be familiar with Shariah audit outlined by BNM since it is considered sufficient for Shariah audit. Shariah auditors should also be familiar with financial statements and internal control systems of an Islamic bank. From the results, it is proposed that the contents of Shariah audit certification should include the areas that Shariah auditors must be well equipped.

Regarding perception on extended contents in Shariah Audit Certification, table 14 shows that the responses Shariah Committee, Shariah Reviewers, and Regulators have mean values above 4. It means the respondents also agreed that the extended contents in Shariah audit should cover the area of business policies, process and procedures, zakat calculation and payment, contracts and agreements, and assessment of financial resource management. It is important to include these contents into Shariah audit certification.

\section{Conclusion}

Shariah audit certification is deemed significant to be implemented in the industry since it enhances the individuals who perform Shariah audit to demonstrate their competency and professionalism in the Shariah auditing field. It will enrich the candidates with educational experience, Shariah and auditing skills, information, and business tools that can be applied immediately in any organization or business environment. The current practice shows that IFIs conducted their own trainings related to Shariah audit. The problem is about the eligibility of the knowldege and skills of the trainers that conduct trainings in Shariah audit. Therefore certification is required.

The results indicate that Shariah audit certification should at least cover the scope of Shariah audit outlined by BNM since it is considered sufficient for Shariah audit. Shariah auditors should also be equipped with knowledge of financial statements and internal control systems of an Islamic bank. More than that, the results suggest that the extended contents in Shariah audit should include the area of business policies, process and procedures, zakat calculation and payment, contracts and agreements, and assessment of financial resource management. It is important to include these contents into Shariah audit certification. This study is expected to contribute to the idea of the contents for Shariah audit certification program to be conducted by the industry association, with collaboration with universities. This certification will also give impact on Shariah audit practices in IFIs. This study can be expanded for future research focusing on the organization which should authorize the certification.

\section{References}

Bank Negara Malaysia (BNM). (2010). Shariah Governance Framework. Malaysia.

Boiral, O., \& Gendron, Y. (2011). Sustainable development and certification practices: Lessons learnt and prospects. Business Strategy and the Environment, 20, 331-347. http://dx.doi.org/10.1002/bse.701

Flint, D. (1988). Philosophy and principles of auditing: An introduction. London: Palgrave Macmillan.

IFSB. (2009). Shariah governance standards.

IIAM. (2010). International standards for the professional practices framework of internal auditing.

Karim, R. A. A. (1990). The independence of religious and external auditors: The case of Islamic banks. Accounting, Auditing \& Accountability Journal, $3(3), \quad 34-44$. http://dx.doi.org/10.1108/09513579010004097

Kasim, N. A. A. (2012). Disclosure of Shariah compliance by Malaysian takaful companies. Journal of Islamic Accounting and Business Research, 3(1), 20-38. http://dx.doi.org/10.1108/17590811211216041

Kassim, N. (2009). Dynamics of Shariah auditing in Islamic financial institutions: A study of the Malaysian islamic financial sector. Unpublished $\mathrm{PhD}$ thesis, Kuliyyah of Economics and Management Sciences, International Islamic University Malaysia, Gombak, Selangor.

Pallant, J. (2011). SPSS survival manual: A step by step guide to data analysis using SPSS (4th ed., p. 359). Crows Nest New South Wales Australia: Allen \& Unwin.

Poksninska, B., Dahlgaard, J. J., \& Eklund, J. R. (2006). From compliance to value-added auditing Experiences from Swedish ISO 9001:2000 Certified Organisations. Total Quality Management, 17(7), 879892. http://dx.doi.org/10.1080/14783360600595294

Rahman, A. R. A. (2010). Shariah audit for Islamic financial services: The needs and challenges. The Journal of Muamalat and Islamic Finance Research, 7(1), 133-145.

Sarea, A. M., \& Hanefah, M. M. (2013). The need of accounting standards for Islamic financial institutions: Evidence from AAOIFI. Journal of Islamic Accounting and Business Research, 4(1), 64-76. 
http://dx.doi.org/10.1108/17590811311314294

Shafii, Z., Salleh, S., Hanefah, H. M. M., \& Jusoff, K. (2013). Human capital development in Shariah Audit. Middle-East Journal of Scientific Research, 13, 28-34. http://dx.doi.org/10.5829/idosi.mejsr.2013.13.1878

Stewart, J., \& Subramaniam, N. (2009). Internal audit independence and objectivity: A review of current literature and opportunities for future research. Paper presented at the Discussions Papers Accounting, Griffith Business School.

Yaacob, H. (2012). Issues and challenges of Shariah audit in Islamic financial institutions: A contemporary view. Paper presented at the 3rd International Conference on Business And Economic Research (3rd ICBER 2012 ) Golden Flower Hotel, Bandung, Indonesia.

Yaacob, H., \& Donglah, N. K. (2012). Shariah audit in Islamic financial institutions: The postgraduates' perspective. International Journal of Economics and Finance, 4(12), 224-239. http://dx.doi.org/10.5539/ijef.v4n12p224

Yahya, Y., \& Mahzan, N. (2012). The role of internal auditing in ensuring governance in Islamic Financial Institution (IFI). Paper presented at the 3rd International Conference on Business and Economic Research (3rd ICBER 2012), Bandung, Indonesia.

\section{Copyrights}

Copyright for this article is retained by the author(s), with first publication rights granted to the journal.

This is an open-access article distributed under the terms and conditions of the Creative Commons Attribution license (http://creativecommons.org/licenses/by/3.0/). 